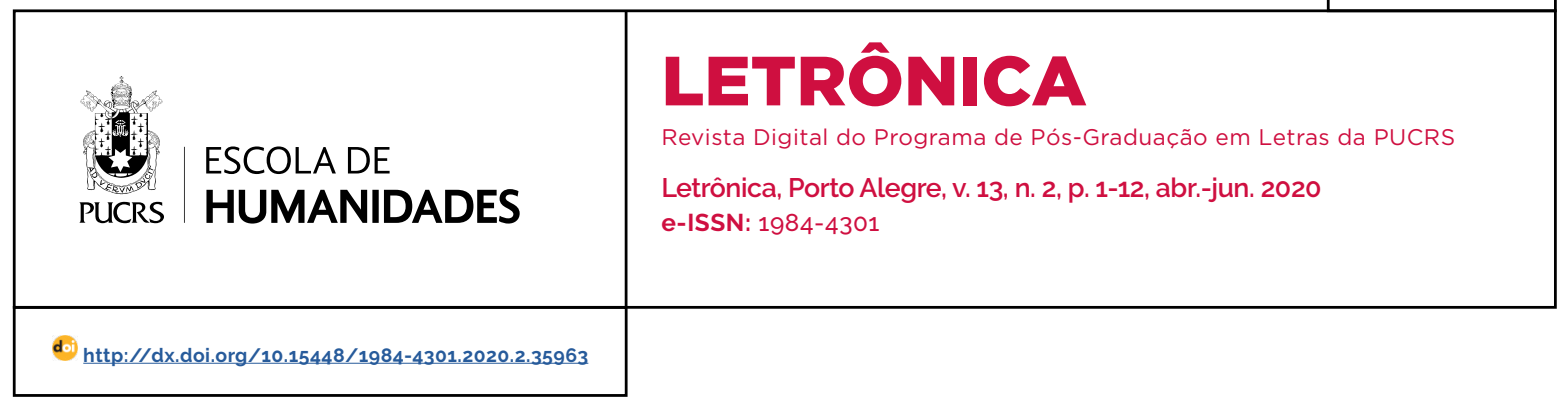

\title{
Encenação e ubiquidade no Twitter: a intolerância dos discursos sobre Marielle Franco
}

\author{
Staging and ubiquity on Twitter: the intolerance of the discourses about Marielle Franco
}

\section{Luis Henrique \\ Boaventura ${ }^{1}$ \\ orcid.org/0000-0001-7760-0184 \\ luishboaventura@hotmail.com}

\section{Ernani Cesar de \\ Freitas $^{1,2}$ \\ orcid.org/0000-0002-8920-9446 \\ nanicesar@terra.com.br}

Recebido em: 11 out. 2019 Aprovado em: 8 mar. 2020 Publicado em: 13 ago. 2020
Resumo: Este artigo trata da encenação do ato de linguagem em interações verbais na rede social Twitter. O objetivo geral é analisar o funcionamento do ato de linguagem na era da hipermobilidade sobre um clima político bipartidário e polarizado em que os parceiros de linguagem abdicam do contrato de comunicação a fim de fortalecerem sua posição original junto a seus pares do discurso político, rejeitando engajar uma negociação legitima de sentido com o lado oposto. O marco teórico se situa sobre a Teoria Semiolinguística, de Patrick Charaudeau (2010), e a comunicação ubiqua de Santaella (2013). A análise recai sobre uma troca linguageira ocorrida no Twitter acerca do assassinato de Marielle Franco e Anderson Gomes, em 14 de março de 2018. Concluímos que as partes opostas implementam a encenação do discurso a fim de conservar suas posições iniciais, o que as impede de considerar pontos de vista dissidentes.

Palavras-chave: Encenação. Comunicação ubiqua. Contrato de comunicação. Polarização. Twitter

Abstract: This article deals with the staging of the language act in verbal interactions in the social network Twitter. The general objective is to analyze the functioning of the language act in the age of hypermobility over a bipartisan and polarized political climate in which language partners abdicate the communication contract in order to strengthen their original position with their peers in political discourse, refusing to engage a legitimate negotiation of meaning with the opposite side. The theoretical framework is based on the Semiolinguistic Theory, by Patrick Charaudeau (2010), and the ubiquitous communication of Santaella (2013). The analysis is based on a language exchange on Twitter about the murder of Marielle Franco and Anderson Gomes on March 14, 2018. We conclude that opposing parties implement the staging of the speech in order to preserve their initial positions, which prevents them from considering dissent points of view.

Keywords: Staging. Ubiquitous communication. Communication contract. Polarization. Twitter.

\section{Introdução}

A revolução midiática que se desenrolava desde meados do séc. XX com o advento da comunicação de massa parece atingir seu estágio final nos últimos anos com a popularização e a penetração social de redes como o Twitter, o Youtube, o Facebook e o WhatsApp (esse sobretudo no Brasil). A realidade está mapeada por sobre a matriz digital, de modo que as redes se tornaram uma interface/representação suficientemente precisa do que é concreto - isto é: o suficiente para impor consequências materiais ainda que a conexão causal seja apenas com mensagens de 280 caracteres em uma tela. Todos entendem, hoje, que a rede social digital constitui o mundo real, em parte porque nada no mundo é mais real em 
seu sentido estrito do que as relações sociais.

Em 14 março de 2018, a então vereadora do Rio de Janeiro, Marielle Franco, e seu motorista, Anderson Gomes, foram executados a tiros em plena luz do dia no bairro Estácio, centro do Rio de Janeiro. O crime segue sem solução até a publicação deste artigo, embora investigação do Intercept Brasil (CAVEIRA: Seis testemunhas apontam ex-policial do Bope como assassino de Marielle Franco, 2019) ter apontado para o envolvimento de milícias do Rio de Janeiro na autoria da execução. Na época, as redes foram tomadas não apenas de histórias fabricadas que visavam à descaracterização de Marielle, mas de comentários que celebravam a sua morte e que contestavam a sensibilização de quem a lamentava. Por exemplo, um tweet de 16 de março do ex-deputado federal Alberto Fraga (DEM-DF), recentemente condenado a seis anos e oito meses de prisão em regime semiaberto pelo crime de concussão (NOVA..., 2018), afirmava falsamente que Marielle Franco era ex-esposa de Marcinho VP (traficante condenado a 36 anos de prisão) e que havia sido eleita pelo Comando Vermelho (facção criminosa carioca). De acordo com dados da FGV/DAPP4 (2019), o tweet viralizou e foi responsável por subsidiar uma onda de informações falsas a respeito da ex-vereadora.

Um estudo amplamente citado de 2012 conduzido por Jonah Berger e Katherine Milkman, da Universidade da Pensilvânia, intitulado "What Makes Online Content Viral?"5, revelou o que viria a se confirmar reiteradamente nos anos seguintes: a raiva é o sentimento que mais propulsiona compartilhamentos nas redes sociais. Apesar de constituir um importante fórum para a troca discursiva da arena pública atual, redes como o Twitter parecem não hospedar ou não evocar a melhor versão possivel dos seus participantes, talvez pela restrição no número de caracteres ou pela maneira como a rede recompensa a impulsividade do usuário - quanto mais cedo e com mais vigor se reage a um fato ou a um trending topic, mais curtidas e retweets se recebe. Por esses e outros motivos a serem discutidos neste artigo, defendemos que a comunicação no Twitter, sobretudo quando negociada em torno de uma matéria altamente polarizante, como a política, tende a firmar contratos exclusivamente entre sujeitos que dividem o mesmo polo da argumentação, visando a uma mútua legitimação e mantendo a construção de sentido presa no interior de um circuito autofágico que gira sobre seu eixo sem sair do lugar. Essa comunicação é ubiqua e seus participantes estão situados de modo ambivalente sobre um espaço social físico e um espaço social virtual. Tal condição, de existência dupla, vem dar origem ao enunciador ubiquo (EUu), que encena o ato de linguagem através de uma articulação entre duas presenças sociais simultâneas: sua projeção virtual e seu correlativo físico.

Como contribuição, entendemos que a encenação do ato de linguagem na ubiquidade requer a conjugação de múltiplos espaços e de ocupação simultânea desses espaços pelos sujeitos, o que nos leva a dizer que o ato, nesse contexto, possui dois circuitos externos, um físico e um virtual, ambos sociais - além do circuito interno, discursivo, que segue sendo singular. Essa nova configuração faz surgir EUu e TUu, sujeitos ubiquos, articulações entre as presenças físicas e virtuais dos sujeitos capazes de enunciar a partir de mais de um lugar ao mesmo tempo. Esperamos que a teoria semiolinguística possa incorporar esses novos sujeitos ao abordar a comunicação nas redes sociais digitais.

O problema de pesquisa deste artigo é enunciado da seguinte forma: como ocorre a encenação do ato de linguagem à luz da comunicação ubiqua e o que motiva a encenação de discursos deliberadamente assimétricos reproduzidos no Twitter? Esta pesquisa investiga a encenação do ato de linguagem em interações verbais nas redes sociais em um contexto de intensa polarização política. O objetivo é analisar a encenação discursiva e a implementação do 
contrato de comunicação entre os sujeitos ubíquos.

A base teórica divide-se sobre a comunicação ubiqua em Lucia Santaella (2010, 2013) e a Teoria Semiolinguistica em Patrick Charaudeau (2010, 2010b). Em Santaella, pesquisadora ligada sobretudo ao estudo da semiótica de Charles Peirce, vamos investigar as noções de hipermobilidade e de ubiquidade (o que está presente em múltiplos lugares de modo simultâneo) que atravessam e conectam essa pesquisa. Já em Charaudeau, vamos nos debruçar sobre a noção de consciência identitária e sobre a Teoria Semiolinguística, sobretudo quanto ao contrato de comunicação, ao ato de linguagem e aos papéis dos sujeitos envolvidos na encenação discursiva. A pesquisa é exploratóriodescritiva, bibliográfica e de caráter qualitativo. O procedimento utilizado foi o observacional e o método de abordagem foi o dedutivo. 0 corpus é composto por uma troca linguageira hospedada no Twitter entre Elza Soares e o usuário @OslecMac74. ${ }^{6}$ A reflexão se organiza em "1 A teoria semiolinguística na análise da comunicação ubíqua" ("1.1 Ubiquidade - Era do onipresente", "1.2 O quadro do ato de linguagem na comunicação ubíqua" e "1.3 O contrato e o destinatário aparente"), "2 Procedimentos metodológicos" e "3 A quebra do contrato de comunicação entre sujeitos ubiquos". A seguir, a fundamentação teórica, seguida da metodologia e da análise do corpus.

\section{A Teoria Semiolinguística na análise da comunicação ubíqua}

A Teoria Semiolinguística do Discurso, proposta por Charaudeau em meados dos anos 1980 dentro do campo da Análise do Discurso, propõe evidências sobre os sujeitos da linguagem com uma abordagem pragmática. Na Teoria Semiolinguistica, os parceiros de comunicação firmam um contrato regido por coerções e pelo qual o sujeito enunciador opera estratégias para alcançar uma finalidade discursiva de acordo com seu projeto de fala. O contrato de comunicação é o "[...] conjunto das condições nas quais se realiza qualquer ato de comunicação [...]" (CHARAUDEAU, 2008, p. 132). Através do contrato comunicacional, "[...] o ato de linguagem torna-se uma proposição que EU faz ao TU e da qual ele espera uma contrapartida de conivência" (CHARAUDEAU, 2010, p. 56, grifo do autor). A organização desse dispositivo pode ser resumida da seguinte forma: "finalidade contratual + [um] projeto de fala" (CHARAUDEAU, 2010, p. 77). A Teoria Semiolinguística toma o fenômeno da enunciação como encenação de um ato de linguagem, cuja noção origina-se de uma abordagem interacionista. A linguagem sob essa perspectiva é tomada como um meio para imprimir ações empreender uma mudança sobre a realidade externa (composta não apenas por objetos, mas por outras pessoas, por laços sociais), o que, em Charaudeau, traduz-se sob a forma das visadas discursivas pelas quais o enunciador tenta impor ao destinatário um determinado comportamento.

O lugar em que é encenado o ato de linguagem é reproduzido por Charaudeau (2010) em uma dinâmica dupla, mas não espelhada, composta pelo circuito externo e pelo circuito interno do dispositivo deste ato. O circuito externo é a arena dos interlocutores, que Charaudeau (2010) chama de parceiros. Eles são seres sociais, reais, historicamente determinados e donos de intenções. São os seres do "fazer", logo: o sujeito comunicante (EUc) e o sujeito interpretante (TUi). Já o circuito interno é o espaço discursivo, dos seres de fala (que Charaudeau também chama de "protagonistas da enunciação", de "estatuto exclusivamente linguageiro"), onde é operada a encenação do ato de linguagem para o sujeito interpretante (um ser social), do outro lado da arena, no espaço situacional junto ao sujeito comunicante. Essa situação de comunicação pode ser ilustrada pelo esquema apresentado na Figura 1:

\footnotetext{
6 Até a publicação deste artigo, a conta do usuário "@OslecMac74" foi suspensa pelo Twitter e, por consequência, todos os seus posts foram apagados. O tweet em questão, no entanto, pôde ser recuperado por printscreen em um acesso em fevereiro de 2019.
} 
Figura 1 - $O$ ato de linguagem e seus sujeitos

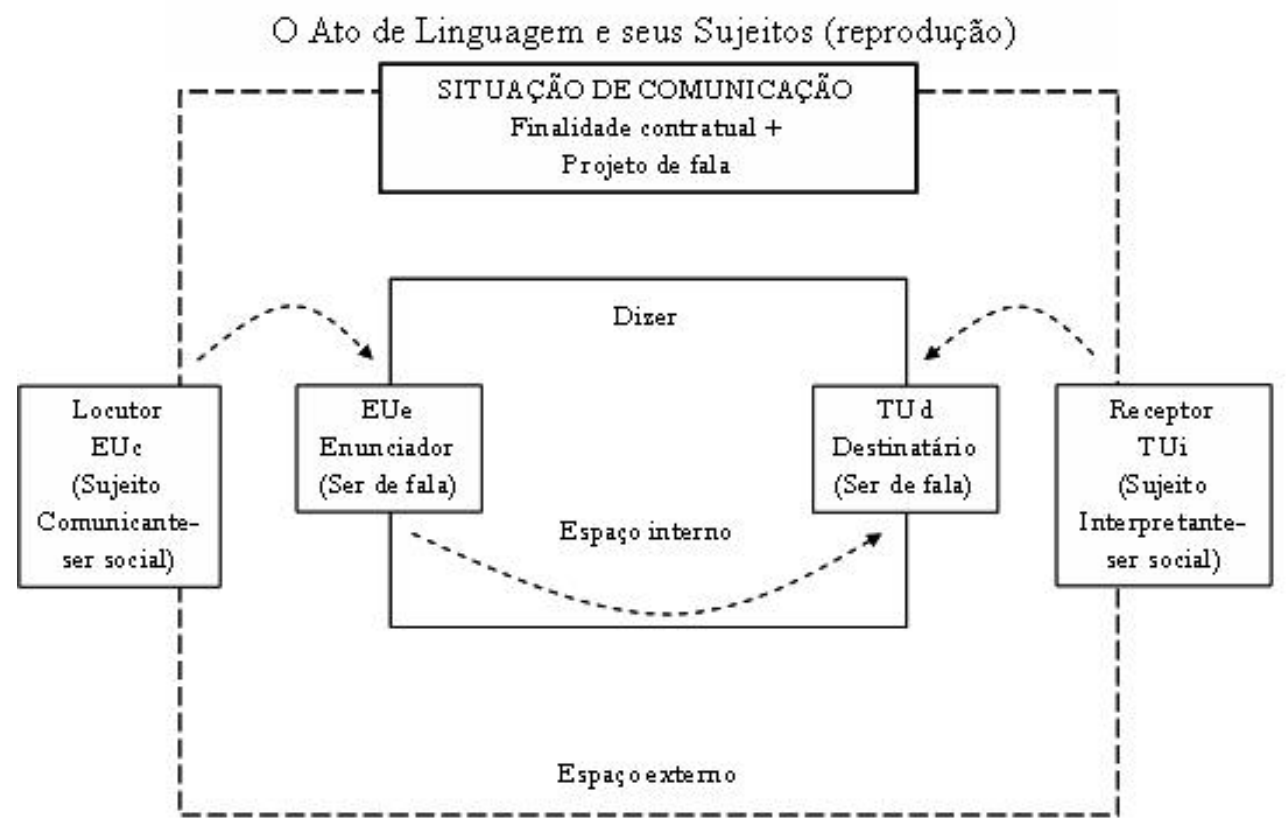

Fonte: Charaudeau (2010, p. 77).

Procuramos na sequência a integração do conceito de comunicação ubíqua pela Teoria Semiolinguística; etapa que consideramos necessária para uma análise discursiva mais completa das trocas linguageiras que ocorrem em novas mídias.

\subsection{Ubiquidade - era do onipresente}

Santaella (2013), ao pensar o lugar dos leitores nas novas mídias, chama a esse indivíduo "não singular" de leitor ubiquo. Adotamos aqui o termo de Santaella de modo um pouco menos especifico; não somente como leitor, mas como "sujeito ubíquo".

Esse novo leitor vem complementar os três tipos de leitor de que fala Santaella (2004): o contemplativo, o movente e o imersivo (SANTAELLA, 2013). De acordo com Santaella (2013, cap. 13, p. 11), "nos últimos dez anos, as transformações por que tem passado a cultura digital e a aceleração dessas transformações são de causar assombro. [...] nesse curto espaço de tempo, surgiu um quarto tipo de leitor que batizei de leitor ubíquo". Para a autora (SANTAELLA, 2014, p. 10), o leitor "é ubíquo porque está continuamente situado nas interfaces de duas presenças simultâneas, a fisica e a virtual [...]". O leitor ubiquo, conectado ao Twitter enquanto pega um metrô em São Paulo, por exemplo, tem a capacidade de ocupar espaços distintos ao mesmo tempo. Enquanto ocupa o espaço fisico, seu lugar de ser física e socialmente determinado (CHARAUDEAU, 2010), ele ocupa também um espaço virtual, do ser projetado na rede (no Twitter, no Facebook, no Tumblr, no Youtube) que, apesar de existir apenas na imaterialidade da nuvem, não deixa de ser também determinado socialmente.

Nossa pesquisa procura dar conta de uma pequena porção desse universo: 0 ato de linguagem negociado entre sujeitos ubíquos em uma hipermobilidade. Para tanto, não devemos, em nenhum momento, perder de vista nossa articulação com Patrick Charaudeau (2010).

\subsection{O quadro do ato de linguagem na comunicação ubiqua}

A estratégia discursiva de captação (CHARAUDEAU, 2010) pretende fazer o interlocutor entrar no universo de pensamento (o próprio ato de comunicação) e, assim, partilhar intencionalidade, valores e emoções do locutor. Quando manifesta identificação com o discurso, o TU abre mão tacitamente de uma prerrogativa de hostilidade ou de contestação, demonstrando frequentar o "universo de pensamento" do EU e coabitar a 
mesma zona de intercompreensão. Já quando a estratégia de captação falha, o TU não se ressente em atacar o conteúdo daquele discurso, pois não deu a ele sua contrapartida de conivência. É sobre esse desencontro entre a produção e a recepção do discurso que se assenta a noção de assimetria (CHARAUDEAU, 2010).
Na comunicação ubíqua, por sua vez, deve-se dispor o ato de linguagem sob parâmetros que levem em consideração as novas dinâmicas introduzidas pelas redes sociais. Propomos representar o ato de linguagem em um contexto de hipermobilidade na Figura 2

Figura 2 - $O$ ato de linguagem na ubiquidade

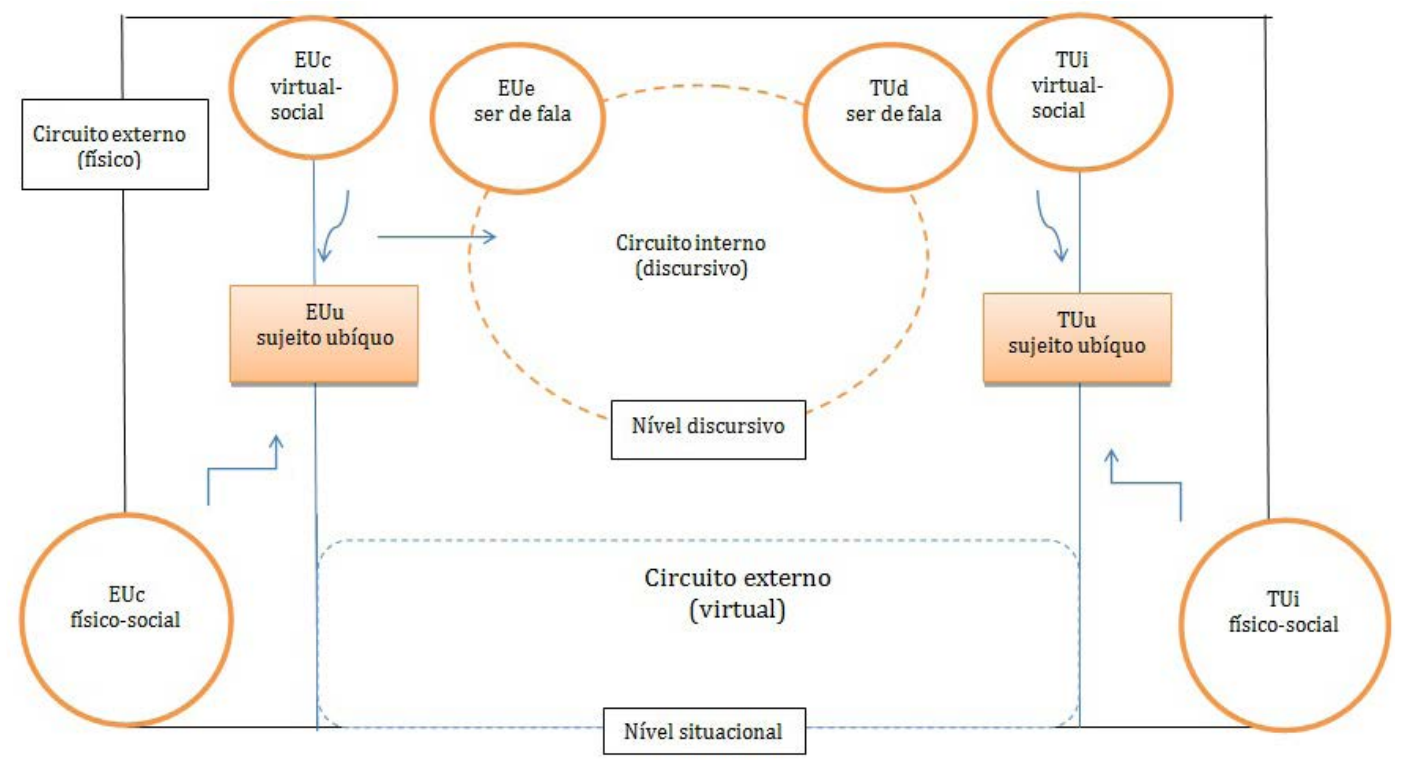

Fonte: Elaborado pelos autores.

Temos representados três circuitos: dois externos, localizados no nivel situacional e, um interno, localizado no nivel discursivo. Temos dois seres físicos, EUc e TUi: ambos projetam dois seres virtuais (lembrando que o TUi virtual é uma projeção de TUi ainda sobre o nivel situacional, não uma projeção de EUc, pois esse se trata de TUd, ser discursivo). EUu e TUu (seres ubiquos) não são sujeitos independentes, mas uma articulação entre ambos os seres sociais (EUc + EUc virtual; TUi + TUi virtual). EUu e TUu são ubíquos porque estão presentes em mais de um lugar social simultaneamente, de acordo com a definição dada por Santaella (2013) a esse sujeito. Desta forma, é EUu quem projeta os seres discursivos EUe e TUd e encena estratégias de discurso de acordo com seu projeto de fala para uma finalidade contratual. Não se pode excluir a projeção EUc virtual pois é através dela que EUc encena seu ato de linguagem na rede social, ou seja, é uma dinâmica entre esses dois seres sociais e historicamente determinados que encena o discurso; apenas a projeção virtual ou apenas o ser físico, isolados, não dão conta de representar a encenação do ato nas redes sociais.

Contudo, esse aporte só se completa ao considerar a questão do contrato e do destinatário aparente, que veremos na sequência.

\subsection{0 contrato e o destinatário aparente}

Como vimos anteriormente (Figura 2), o ato de linguagem na ubiquidade deve ser desenhado de maneira um pouco diferente em relação ao quadro apresentado inicialmente por Charaudeau (2010). Ao tratar da comunicação ubiqua, Santaella (2013) fala de um espaço virtual justaposto ao espaço físico e de um sujeito capaz de estar em múltiplos lugares simultaneamente. Por exemplo, estar presente fisicamente em um protesto na avenida de um grande centro urbano e estar conectado postando mensagens ou, ainda, transmitindo conteúdo audiovisual em tempo real no Twitter. 
Esse sujeito estaria presente fisicamente na rua, espaço social, e presente virtualmente no Twitter, também um espaço social. A presença e ação em dois lugares ao mesmo tempo dão a este sujeito o status de sujeito ubíquo.

Nesta pesquisa, falamos de um ato de linguagem encenado por sujeitos ubiquos, e esse ato envolverá um contrato de comunicação (CHARAUDEAU, 2010) sujeito a coerções e aberto a estratégias. Contudo, não percamos de vista que esse ato de linguagem se dará sobre um quadro densamente polarizado (um espectro polarizante), no qual os sujeitos envolvidos acreditam existir apenas um lado certo (o seu); o outro lado seria, por consequência, errado em sua fundação, indefensável e cujos valores são inaceitáveis para o sujeito. Diante de um cenário que se desenha a priori desse modo, o sujeito não envolverá no seu projeto de fala a finalidade contratual de seduzir ou persuadir o destinatário do outro lado do espectro por considerar que esse está além de seu alcance. Pelo contrário, o sujeito tratará de antagonizar esse destinatário. A direção verdadeira do ato do enunciador, portanto, é a de um segundo destinatário, uma instituição destinatária composta por pessoas que estão do mesmo lado do enunciador no espectro polarizante. O contrato é firmado não com o primeiro destinatário, aparente, mas com o segundo. Como a identidade do EU define-se a partir do outro, ele fortalece sua identidade em um movimento duplo: 1) quanto mais diferente do antagonista da encenação (original poster, o autor do tweet); e 2) e quanto mais semelhante ao grupo junto ao qual ele busca validação.

Cumprindo esses dois movimentos, o enunciador deixa a troca linguageira com sua identidade não apenas intacta, mas fortalecida. Em um cenário ideal, suporiamos que uma troca linguageira que ocorre sobre um tema polêmico, por mais polarizado que seja, envolveria sujeitos buscando seduzir/persuadir um ao outro. Não é esse o cenário que vemos na materialidade do corpus que analisamos neste estudo. De acordo com Charaudeau (2012, p. 6. grifos do autor), "[s]e não há possibilidade de reconhecer tal contrato, o ato de comunicação não estabelece pertinência e os parceiros não possuem direito à palavra". De fato, o enunciador não oferece a OP o direito à palavra, não o legitima para a troca e não se alia a ele para construção de sentido. Dessa forma, podemos afirmar que não é com ele que o enunciador firma seu contrato.

Detalhamos na sequência os procedimentos metodológicos. O desafio será estabelecer com clareza os lugares desses sujeitos e a dinâmica da encenação do ato de linguagem em que a assimetria é deliberada pelos participantes do ato.

\section{Procedimentos metodológicos}

Nosso marco teórico está apoiado sobre duas bases: 1) semiolinguística do discurso, de Charaudeau $(2001,2010)$ e 2) comunicação ubíqua, de Santaella (2010, 2013, 2014). Essas duas bases teóricas se conectam da seguinte forma: de acordo com o quadro do ato de linguagem de Charaudeau (2010), EUc (ser físico/social) projeta EUe (ser de discurso) e TUd (ser de discurso), encenando seu ato de linguagem para TUi (ser social). Em nosso caso, afirmaremos que EUc (ser fisico/social) projeta EUc virtual (ser virtual/social); como ambos são seres sociais, a articulação entre eles forma EUu (ser ubiquo, manifesta-se em dois lugares sociais ao mesmo tempo). EUu projeta EUe (ser de discurso). Da mesma forma, TUi é uma instituição destinatária composta por usuários do Twitter, sendo que o usuário está presente simultaneamente no plano físico (TUi físico/social) e no virtual (TUi virtual/social) do Twitter, manifestando-se como TUu, de leitores ubíquos (SANTAELLA, 2013), ocupantes de dois espaços sociais (físico e virtual) ao mesmo tempo.

Charaudeau (2001) concebe "ato de linguagem" como o combinado entre circuitos interno e externo do ato onde se estabelece o contrato de comunicação, marcado por coerções e com margens sob as quais o sujeito desenvolve estratégias discursivas para cumprir sua finalidade e seduzir ou persuadir seu destinatário, impondothe determinado comportamento.

No que diz respeito à encenação do ato na comunicação ubíqua, em Santaella (2013), supomos o ato de linguagem na hipermobilidade 
de um modo um pouco diferente. Nossa hipótese fala de dois circuitos externos, espaço físico e espaço virtual (em nosso caso, do Twitter), ambos espaços sociais, no nivel da situação de comunicação. Consequentemente somos obrigados a falar de seis sujeitos: EUc físico, EUc virtual e EUe; TUi físico, TUi virtual e TUd. Os seres físicos e virtuais, contudo, recombinam-se em uma dinâmica que batizamos, neste estudo de tese (BOAVENTURA, 2017), de EUu e TUu, sujeitos ubiquos, presentes em mais de um lugar (físico e virtual) ao mesmo tempo. Nessa configuração, EUu projeta os seres de discurso EUe e TUd.

Será analisado, a título de ilustração, o tweet do usuário @OslecMac74, de 3.294 seguidores, em resposta ao tweet de Elza Soares, de 49.800 seguidores (os números de ambas as contas são referentes a 12 de fevereiro de 2019). Nesse contexto, chamamos Elza Soares de OP (original poster), termo comum em fóruns de internet para identificar o "mensageiro original" a partir do qual se desenrola o debate e demais comentários. @ OslecMac74 será identificado como enunciador EUu. Seu parceiro de comunicação, TUu, na encenação discursiva que iremos analisar, não é Elza Soares, a quem cabe mero papel de destinatário aparente, mas seus seguidores e demais pessoas ocupantes do lado comum do espectro de @OslecMac74 para o qual o enunciador deseja "sinalizar virtude". EUu/TUu são sujeitos ubíquos resultantes da articulação entre os sujeitos sociais físico e virtual. EUc físico + EUc virtual $=$ EUu; TUi físico + TUi virtual $=$ TUu. O sujeito ubíquo é psicossocial, ocupa múltiplos espaços sociais simultaneamente, além de estar no nivel situacional do discurso e de ser responsável por projetar os seres de fala, sujeitos discursivos.

Detalhamos na análise a seguir o porquê de Elza Soares não configurar, sob a perspectiva do enunciador EUu @OslecMac74, um TUu válido com o qual seja pertinente estabelecer um contrato de comunicação, utilizando-a como ferramenta (destinatário aparente) em sua encenação cuja visada discursiva é endereçada a um segundo destinatário em troca de uma contrapartida de conivência na moeda de troca da rede social em questão: curtidas, retweets e novos seguidores para alavancagem de relevância social na hierarquia da rede, o que significa maior alcance e relevância.

Cabe, finalmente, um esclarecimento a respeito da terminologia. Utilizamos o termo "espectro polarizante" (BOAVENTURA, 2017) para definir o quadro de convicções bipartidário sobre o qual se desenrolam os discursos extremos e a assimetria deliberada na internet, embora tais questões se apliquem também à sociedade física, fora da rede. Essas convicções podem ser de toda sorte: politicas, religiosas ou plenamente fúteis, desde que dividam os sujeitos que gravitam em torno delas em um sistema de discussão binário, ou seja, dois grupos opostos bem distintos. $\mathrm{O}$ diálogo e o entendimento ficam severamente comprometidos, principalmente na internet, em temas que se desenvolvem sobre esse quadro polarizado, representado a seguir na Figura 3.

Figura 3 - O espectro polarizante

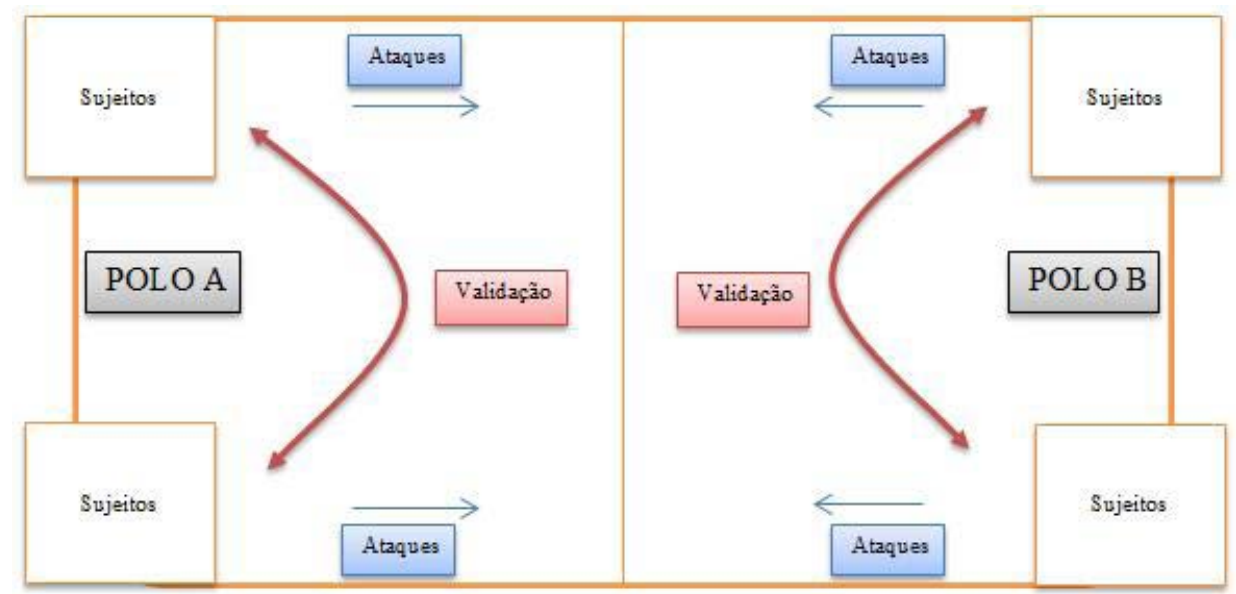

Fonte: Boaventura (2017). 
A nomenclatura dos polos, "direita" vs. "esquerda", é uma simplificação. Esse antigo binômio político não tem uma carga semântica fixa em todos os lugares do mundo nem ao longo do tempo. O modo como esses termos são usados e a configuração dos discursos em torno deles é um tema pertinente para outra pesquisa. Veremos na sequência a análise do corpus de acordo com os pressupostos teóricos de Charaudeau e de Santaella.

\section{A quebra do contrato de comunicação entre sujeitos ubíquos}

Procuramos selecionar uma troca linguageira típica das horas que se sucederam ao anúncio do assassinato de Marielle Franco e Anderson Gomes, com o único critério de que os envolvidos tivessem um alcance amplo na rede social. Desta forma, chegamos ao exemplo que segue, um tweet de Elza Soares e uma resposta do usuário @OslecMac74 (embora seu nome real esteja divulgado de forma pública em suas redes sociais, optamos aqui por nos referir a ele apenas pelo nome de usuário).

Segue abaixo o primeiro tweet, ilustrado na Figura 4, o tweet de Elza Soares (49 mil curtidas, 20 mil retweets e 234 comentários):

Figura 4 - Tweet de Elza Soares

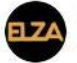
Elza Soares @ElzaSoares

Das poucas vezes que me falta a voz. Chocada. Horrorizada. Toda morte me mata um pouco. Dessa forma me mata mais. Mulher, negra, lésbica, ativista, defensora dos direitos humanos. Marielle Franco, sua voz ecoará em nós. Gritemos.

20:46 - 14 de mar de 2018

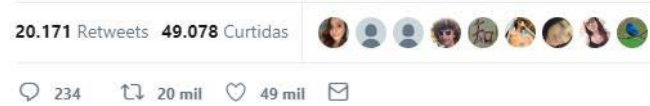

Fonte: Twitter (2019).7
Na sequência, Figura 5, o tweet de @Oslecmac74 (192 curtidas, 12 retweets e 30 comentários):

Figura 5 - Tweet de @Oslecmac74

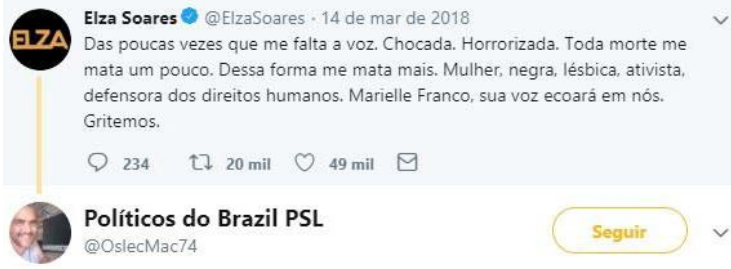

Em resposta a @izzsoares

Hum, quando vc se chocar sobre a morte do policial que foi executado com 30 tiros de fuzil, aí eu vou respeitar vossa opinião... 22:02 - 14 de mar de 2018

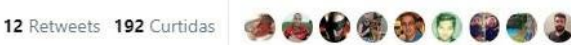
$\bigcirc 30 \quad$ tᄂ $12 \quad \bigcirc \quad 192 \quad \square$

Fonte: Twitter (2019). ${ }^{8}$

Os papéis linguageiros dos sujeitos presentes no ato de linguagem são os seguintes: OP (original poster)/ destinatário aparente: Elza Soares; Enunciador (EUu): @OslecMac74; Destinatário (TUu-instituição destinatária): público/ seguidores de @OslecMac74.

O tweet de @OslecMac74 possui 192 curtidas e 12 retweets, ou seja, sua mensagem foi objetivamente aprovada por um público de cerca 200 pessoas, além das que leram, concordaram, mas não chegaram a utilizar o botão "curtir" ou "retweetar" (o que constitui a maioria nas redes sociais: o leitor registra, forma um juizo de valor e segue em frente, scrolling down). Esse público constitui o destinatário verdadeiro do EUu @OslecMac74. Podemos representar essa dinâmica sobre o espectro polarizante na Figura 6, da seguinte forma: 
Figura 6 - O verdadeiro destinatário do EUu @OslecMac74 no espectro polarizante

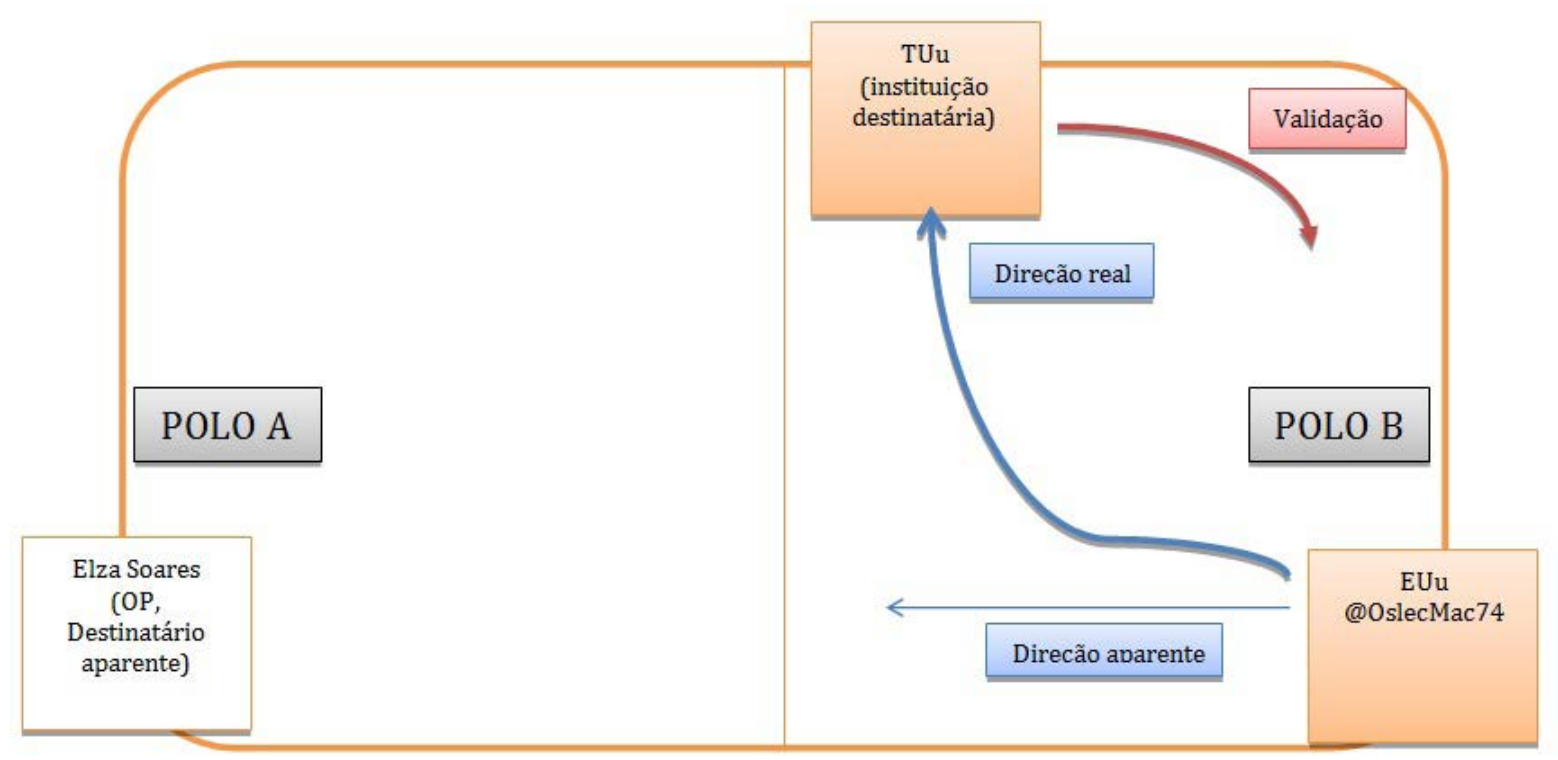

Fonte: Elaborado pelos autores.

EUu @OslecMac74 se coloca à direita, Polo B, e posiciona o antagonista de sua encenação, a OP Elza Soares, à esquerda, no Polo A. Para evitar a repetição da Figura 2, pedimos ao leitor que retorne a ela e posicione @OslecMac74 no lugar do EUu e os Seguidores/público desse enunciador no lugar do TUu, de modo a observarmos com mais clareza a intersecção entre as teorias de Charaudeau (2010) e Santaella (2013). Na sequência vamos explicar e analisar as duas figuras.

Pode-se colocar que a Figura 6 contém a Figura 2. O que podemos reparar de início é que o destinatário aparente, Elza Soares (OP), não faz parte do quadro do ato de linguagem encenado por @OslecMac74 (EUu). Isso ocorre porque o enunciador não o contempla em seu projeto de fala: a direção do seu ato de linguagem é outra, representada pela seta azul mais espessa, direção verdadeira do seu discurso, em detrimento da direção aparente, representada na seta azul mais fina. Recordemos o que os dois lados do espectro representam: o Polo A, a "esquerda"; o polo B, a "direita". Ao enunciador só interessa o seu lado do espectro polarizante. Conforme já discorremos anteriormente, não há entre EUu e OP, destinatário aparente, saberes partilhados suficientes, tampouco um imaginário sociodiscursivo comum. Maingueneau (2005) diria que os sujeitos não compartilham a mesma cena validada. Por sua vez, Charaudeau (2012) trata, muitas vezes, em sua Teoria Semiolinguística, da questão da legitimidade para falar, de um estatuto que não pode ser autoconferido, mas precisa ser reconhecido pela figura do outro.

O enunciador oferece resposta (reply) ao autor do tweet, mas não reconhece sua legitimidade para a troca já que não busca com ele "princípios, pertinência, influência e regulação comuns" (CHARAUDEAU, 2012, p. 1). O contrato é firmado não com o autor do tweet, destinatário aparente do enunciador, mas com a instituição destinatária formada por seu público e seguidores, que dividem com ele o mesmo imaginário sociodiscursivo, o mesmo lado do espectro polarizante. Ao retornar à mensagem, vemos que o enunciador EUu afirma não respeitar no presente momento a opinião daquele com quem se engajou na troca linguageira, o que é em si mesmo oximoro. Não respeitar a opinião daquele com quem se argumenta implica a futilidade do próprio argumentar. Diante disso, o enunciador parece não desejar ter suas convicções e saberes desafiados, tampouco deseja desafiar as convicções e saberes do autor do tweet, fazendo com que esse habite seu universo de pensamento (CHARAUDEAU, 
2010). A construção do enunciado é um indício de que o enunciador se fecha em sua consciência identitária ao invés de colocá-la no campo aberto da troca linguageira e toma, de fato, o caminho oposto: EUu antagoniza OP ao invés de estabelecer com ele o contrato comunicacional, cedido, por sua vez, à instituição destinatária TUu, composto pelo público de quase 200 pessoas que aprovaram o tweet de EUu e para o qual é encenado o ato de linguagem em que EUu é virtuoso e OP é antagônico.

Este jogo identitário leva os participantes do espectro polarizante a recusar similaridades e a acentuar diferenças com aqueles que, sob sua perspectiva, ocupam o polo oposto. Como aponta Charaudeau (2009, p. 312), "[...] o risco está no fato de que, ao rejeitar o outro, o eu não disponha mais da diferença a partir da qual se definir; ou, ao torná-lo semelhante, perca um pouco de sua consciência identitária [...]". O jogo de regulação da consciência identitária do sujeito visa à preservação e o fortalecimento de sua identidade, o que ocorre por um duplo movimento: 1) quanto mais diferente do antagonista (OP Elza Soares); e 2) quanto mais semelhante a TUu.

Em seu ato de linguagem, o EUu @OslecMac74 projeta os seres de discurso EUe e TUd, esse representado na figura não de Elza Soares, como já abordamos, mas do seu público imaginado de pessoas do seu lado do espectro polarizante. O projeto de fala de EUu é claro: buscar validação junto ao seu grupo; para isso, EUu deve impor ao seu destinatário um determinado comportamento através da estratégia discursiva de captação (CHARAUDEAU, 2010). Como nos lembram Barbisan et al. (2010, p. 128, grifo do autor), "a captação consiste em seduzir ou persuadir o interlocutor, provocando nele certo estado emocional". Desse modo, a finalidade contratual de EUu busca "estabelecer uma relação de influência entre locutor e interlocutor num comportamento ALOCUTIVO" (CHARAUDEAU, 2010, p. 82, grifo do autor).

O EUu impõe ao TUu-instituição destinatária a visada discursiva de "fazer-concordar", validando o seu discurso através de ferramentas como o "curtir", o "retweetar" ou por meio de uma resposta de apoio. Segundo Charaudeau (2010, p. 82), "o sujeito falante enuncia sua posição em relação ao interlocutor no momento em que, com o seu dizer, o implica e lhe impõe um comportamento. Assim, o locutor age sobre o interlocutor". Não podemos avaliar a reação de quem apenas concordou em silêncio, mas no caso das quase 200 pessoas que reagiram utilizando o botão "curtir", é possivel concluir que o ato de linguagem de EUu cumpriu sua finalidade contratual e impôs a esses sujeitos, constituintes de TUu-instituição destinatária, um comportamento específico, utilizando uma das ferramentas disponibilizadas pelo Twitter para expressar conformidade ou dar sua "contrapartida de conivência" (CHARAUDEAU, 2010, p. 56). Eles tiveram suas convicções asseveradas pelo tweet de EUu, em razão do qual procederam a recompensar EUu com uma "curtida", moeda de troca, como já dito, na economia da rede social

O contrato de comunicação proposto por EUu é firmado com TUu-instituição destinatária, e não OP. O ''contrato de comunicação' une os parceiros num tipo de aliança objetiva que lhes permite coconstruir sentido se autolegitimando" (CHARAUDEAU, 2012, p. 6, grifo do autor). EUu não constrói o sentido junto de OP, tampouco o legitima para troca nem deseja sua legitimação. Por isso a OP Elza Soares não é destinatário verdadeiro de EUu; o destinatário com quem EUu firma o contrato, constrói sentido e negocia legitimação são os destinatários do seu lado do espectro. Desde que essa narrativa seja legitimada, ainda que em um círculo autofágico que se retroalimenta sem entrar em contato real com a visão do outro, sem se colocar à mercê de um desafio discursivo, EUu terá satisfeito sua finalidade contratual com TUu e ambos deixarão a arena discursiva com suas identidades reforçadas e ainda mais arraigados em suas próprias concepções.

\section{Considerações finais}

Até que ponto o Twitter significa o lócus contemporâneo da arena pública onde são trocados discursos com o poder de determinar os 
rumos da nossa sociedade? Em 2018, por exemplo, nos Estados Unidos, a juíza federal Naomi Reice Buchwald sentenciou como inconstitucional que o Presidente Donald Trump bloqueie usuários de seu perfil no Twitter. $^{9}$ Buchwald escreveu na sentença que o Twitter é um "fórum público designado" e que o presidente do país não tem o poder para prevenir que pessoas acompanhem suas declarações. Em vista do fato de que o mecanismo de "sense-making" da nossa sociedade se transportou para a interface virtual da realidade, não podemos perder de vista as consequências que a negociação de sentidos na arena virtual traz ao plano concreto.

O tema da presente pesquisa é a encenação do ato de linguagem na rede social Twitter, em que a comunicação é ubiqua, atravessada pela hipermobilidade e negociada por sujeitos ubiquos, ocupantes de múltiplos espaços sociais ao mesmo tempo. Como tratamos, a rede social Twitter foi selecionada por considerarmos que o ritmo veloz de comunicação que ocorre na rede. bem como a indexação de tópicos por meio de hashtags, fizeram dela, ao longo dos anos, um fórum de debate a respeito dos assuntos discutidos no momento capaz de emoldurar com precisão a temperatura da opinião pública.

Foi formulado o seguinte problema de pesquisa: como ocorre a encenação do ato de linguagem à luz da comunicação ubíqua e o que motiva a encenação de discursos deliberadamente assimétricos reproduzidos no Twitter? O objetivo, por sua vez, foi analisar as razões para a não implementação do contrato de comunicação entre os sujeitos ubiquos.

Conferimos, a partir da análise do corpus, que os sujeitos ubiquos EUu e TUu negociam entre si uma contrapartida de conivência com o propósito de reforçar suas consciências identitárias. O enunciador EUu (usuário @OslecMac74) encena um ato de linguagem que tem como visada discursiva o "fazer concordar", em que busca a aprovação de TUu para seus discursos na forma das ferramentas oferecidas pela rede social Twitter através do "curtir" ou do "retweet", moedas de economia social. Seus destinatários reais são o público, formado por seus seguidores ou não, com que compartilha o mesmo lado no espectro polarizante. A destinatária Elza Soares, OP, a quem o EUu oferece seu tweet de resposta, constitui apenas um destinatário aparente, objetificado em sua encenação discursiva como antagonista do ato de linguagem, representante do polo oposto do espectro. O propósito do projeto de fala do enunciador EUu não envolve persuasão ou influência para seu destinatário aparente, apenas para TUu, público que habita o mesmo polo de EUu no espectro e divide com ele suas crenças e convicções. Estabelecer com esse outro um contrato de comunicação significa expor sua consciência identitária ao desafio de entrar em contato com aquilo que lhe é diferente; ao invés disso, o sujeito encena com esse outro, do lado oposto do espectro, um ato de comunicação deliberadamente assimétrico e busca validação do discurso junto ao seu grupo, no polo comum do espectro.

Entendemos, portanto, que ao lançar seu olhar sobre o outro, o individuo constrói sua consciência identitária e se constitui como sujeito, colocando-se em um polo do espectro e posicionando o outro, quando identificado como seu "diferente", no polo oposto. Isso ocorre porque $\mathrm{o}$ ato de linguagem transcorre no que chamamos "espectro polarizante" (por exemplo, no caso do contexto político nacional, os polos são "esquerda" e "direita"), sobre o qual os sujeitos se organizam em grupos dos que compartilham de suas convicções e dos que não compartilham.

Esperamos que este artigo contribua para a ampliação das aplicações possiveis da Teoria Semiolinguística do Discurso de Charaudeau, bem como as noções recentes trazidas por Lucia Santaella a respeito da comunicação ubíqua. Que a análise discursiva deve abordar as trocas linguageiras no espaço virtual está claro há muitos anos, mas o que não era claro até pouco tempo é a necessidade de alternar constantemente entre a realidade física e a sua representação nas redes sociais para encontrar a versão mais

9 "Trump can't block Twitter followers, federal judge says". Disponivel em: https://www.cnbc.com/2018/05/23/trump-cant-block-twitter-followers-federal-judge-says.html. Acesso em: 19 fev. 2019. 
detalhada ou próxima possivel da verdade. A profusão dos discursos de ódio e de intolerância nas redes sociais nos últimos anos, sobretudo na segunda metade desta década, tornam urgente a necessidade dessa análise. Casos em que o ódio e a falta de humanidade chocaram nas redes sociais, como as reações às mortes de Dona Marisa Letícia e de Marielle Franco e à morte do neto do ex-presidente Lula, ou ações organizadas, como a campanha caluniosa que levou ao fechamento da exposição Queermuseu em Porto Alegre, além de muitos outros exemplos, exigem um olhar teórico-metodológico.

Há uma velha ideia transcultural, presente em mitos e narrativas religiosas sem conexão aparente entre si, de acordo com a qual a realidade é trazida à existência por meio da palavra. Em "Deus disse 'faça-se a luz'. E a luz foi feita", em Gênesis I do Antigo Testamento, a palavra-chave é "disse". Mesmo uma divindade todo-poderosa precisa utilizar a língua para "criar"10 a realidade. Negociamos a realidade todos os dias, constantemente, através da linguagem; e evocamos todo tipo de coisa à existência através dos sentidos que negociamos. Podemos trazer à realidade uma sociedade mais ou menos tolerante, mais ou menos racista, mais ou menos autoritária dependendo do que se rejeita ou do que se aceita como norma na arena pública, do qual logo as redes sociais se tornarão seu principal "fórum público designado", razão porque é imperativo que se preste atenção aos discursos e transformações sociais promovidas em arenas como o Twitter.

\section{Referências}

BERGER, J; MILKMAN, K. What Makes Online Content Viral. Disponivel em: https://doi.org/10.1509/ jmr.10.0353. Acesso em: 19 fev. 2019. https://doi. org/10.1509/jmr.10.0353

CAVEIRA: Seis testemunhas apontam ex-policial do Bope como assassino de Marielle Franco. The Intercept Brasil. Disponivel em: https://theintercept. com/2019/01/17/quem-matou-marielle-franco-bope. Acesso em: 11 fev. 2019.
CHARAUDEAU, P. Uma teoria dos sujeitos da linguagem. In: LARA, Glaucia Muniz Proença; MACHADO, Ida Lúcia; EMEDIATO, Wander. Análises do discurso hoje. Rio de Janeiro: Nova Fronteira, 2008. p. 11-30. v. 1.

CHARAUDEAU, P. Identidade social e identidade discursiva, o fundamento da competência comunicacional. In: PIETROLUONGO, Márcia (org.). O trabalho da tradução. Rio de Janeiro: Contra Capa, 2009. p. 309-326.

CHARAUDEAU, P. Linguagem e discurso: modos de organização. São Paulo, 2010.

CHARAUDEAU, P. O contrato de comunicação na sala de aula. Inter-Ação, Goiânia, v. 37, n. 1, p. 1-14, 2012. https://doi.org/10.5216/ia.v37i1.18861

NOVA condenação de Alberto Fraga é de 6 anos e 8 meses de prisão. Correio Braziliense. 2019. Disponivel em: https://www.correiobraziliense.com.br/app/noticia/cidades/2019/02/09/interna_cidadesdf,736440/ nova-condenacao-de-alberto-fraga-e-de-6-anos-e-8-meses-de-prisao.shtml. Acesso em: 11 fev. 2019.

SANTAELLA, L. Culturas e artes do pós-humano: da cultura das mídias à cibercultura. São Paulo: Paulus, 2003.

SANTAELLA, L. Comunicação ubiqua: repercussões na cultura e na educação. São Paulo: Paulus, 2013. [e-book]

SANTAELLA, L. Sociotramas: estudos multitemáticos sobre redes digitais. São Paulo: Estação das Letras e Cores, 2014

\section{Luis Henrique Boaventura ${ }^{1}$}

Doutor em Letras pela Universidade de Passo Fundo (UPF, Passo Fundo, RS, Brasil), bolsista PNPD/CAPES (UPF).

\section{Ernani Cesar de Freitas ${ }^{1,2}$}

Pós-doutorado em Linguística Aplicada e Estudos da Linguagem pela Pontificia Universidade Católica de São Paulo (PUC-SP/LAEL, São Paulo, SP, Brasil), professor da Universidade de Passo Fundo (UPF) em Passo Fundo, RS, Brasil, e professor da Universidade Feevale, em Novo Hamburgo, RS, Brasil.

\section{Endereço para correspondência}

Luis Henrique Boaventura

Universidade de Passo Fundo

Av. Brasil Leste, 285, Prédio B4, Sala PPGL

São José, 99052-900

Passo Fundo, RS, Brasil

\footnotetext{
10 De acordo com a perspectiva pós-moderna, grosso modo, o homem cria a realidade socialmente através da linguagem (Foucault Derrida). Para a abordagem moderna, por outro lado, a realidade é dada ao homem e esse está limitado a mediá-la e organizá-la pela lingua (Peirce, Saussure).
} 